\title{
Medical arbitration and claims for malpractice related to health service users under 15 years of age during 2011-2015
}

\author{
Sonia B. Fernández-Cantón* and José N. Rizo-Amézquita \\ Dirección General de Difusión e Investigación de la Comisión Nacional de Arbitraje Médico, Mexico City, Mexico
}

\begin{abstract}
Background: Claims by health services users are a negative indicator of the care quality. To know the situations that originate them and their consequences are key issues to consider in order to design strategies to improve the quality of healthservices. This study analyzes the cases submitted to the National Medical Arbitration Commission with a final arbitration decision during the period 2011-2015, related to health service users younger than 15 years old. Methods: This was a cross-sectional descriptive study. We analyzed information extracted from the reports with a final arbitration decision in the past 5 years, selecting those where the affected users were younger than 15 years old. Results: $A$ total of 40 case arbitral awards were found, most of them involving pediatric services with a similar number of male and female users and a similar proportion in the extreme age groups, $<1$ year (32\%) and 10-14 years (30\%). The main cause of the complaint was related to diagnostic procedures (45\%). An average of 8.7 adverse events per case was identified, most of them associated with procedures. Among the damages, there were 12 deaths and 9 permanent disabilities. There was evidence of malpractice in $65 \%$ of the cases and the sentence was condemnatory in $60 \%$ of the cases. Conclusions: This manuscript shows information in four main sections: sociodemographic characteristics, description of medical care, adverse events and their repercussions on health damages, evaluation of the medical act, and conclusions of the arbitration process.
\end{abstract}

Key words: Medical controversies. Claims. Medical arbitration. Malpractice. Adverse events.

\section{El arbitraje médico y las quejas concluidas relacionadas con la población de menores de 15 años durante el periodo 2011-2015}

\section{Resumen}

Introducción: Las quejas constituyen un indicador negativo en la calidad de la atención médica. El conocimiento de los problemas que las originan y sus consecuencias constituyen elementos fundamentales para las estrategias de mejora de la calidad. En este estudio se dan a conocer los resultados del análisis de laudos concluidos, emitidos por la Comisión Nacional de Arbitraje Médico durante el periodo 2011-2015, que corresponden a la población usuaria menor de 15 años. Métodos: Estudio transversal descriptivo. Se analizó información extraída de los laudos concluidos en los últimos 5 años en

Correspondence:

*Sonia B. Fernández-Cantón

E-mail: sonia_fernandez@prodigy.net.mx

DOI:10.24875/BMHIME.M18000038
Available online: 14-11-2018 Bol Med Hosp Infant Mex. 2018;75:160-170

www.bmhim.com 
los que la población afectada tuviera menos de 15 años, independientemente del servicio involucrado. Resultados: Se detectaron 40 laudos, la mayoría involucrados con servicios de pediatría, encontrándose una distribución homogénea por edad y sexo. Los porcentajes más altos se encontraron en las edades extremas de la población estudiada: menores de 1 año (32\%) y de 10 a 14 años (30\%). La principal causa de la queja fueron los problemas con los auxiliares de diagnóstico (45\%). Se detectó un promedio de 8.7 eventos adversos por caso, la mayoría relacionados con procedimientos. Entre los daños destacan 12 defunciones y 9 discapacidades permanentes. Se encontró evidencia de mala práctica en el $65 \%$ de los casos y hubo una sentencia condenatoria en el $60 \%$ de los laudos. Conclusiones: Se obtuvieron resultados en cuatro grandes apartados: características sociodemográficas, descripción de la atención médica, eventos adversos y sus repercusiones en los daños a la salud, y la evaluación del acto médico y conclusiones del laudo.

Palabras clave: Controversias médicas. Quejas. Arbitraje médico. Mala práctica. Eventos adversos.

\section{Introduction}

This paper aims to address the importance of the medical complaint concerning the processes to improve the quality of care and the fundamental role played by the National Medical Arbitration Commission (CONAMED, for its Spanish acronym) since its creation. Indeed, since 1996, this institution has as its principal function to offer alternative mechanisms for the solution of disputes arising from health care, which represents significant advantages for those who are involved in this type of conflict.

Although the majority of medical complaints related to pediatric services are solved through the conciliation process, it is essential to address, in a complementary manner, what happens with that other segment of complaints (approximately $3 \%$ ). In these cases, when they are not solved during the conciliation phase, the interested parties decide to opt for medical arbitration and leave it up to an institutional expert to resolve the conflict.

In this context, the analysis of medical complaints that were resolved through the issuance of an arbitral award $^{\text {a }}$ during the period 2011-2015, regardless of the nature of the sentence handed down is addressed. The results refer to the project ARIEL (Automation of Statistical Information Registries on Awards) (ARIEL for its Spanish acronym $)^{1}$, corresponding to those years for the user population demanding of children under 15 years of age.

It is important to highlight that the complaints that are solved through medical arbitration represent the most complex cases, which could not be resolved by the other alternative mechanisms offered by CONAMED (consultancies, immediate negotiations, and conciliations). In that sense, its analysis represents, in a

\footnotetext{
a An arbitrary award is understood as the final specialized resolution pronounced by the arbitration expert (in this case, CONAMED), whereby the controversy between the two parties involved is brought to an end.
}

significant way, the negative impact of the quality of medical care on patient safety.

As a generic antecedent of the proposed analysis, it is convenient to point out that, until a few years ago, the approach to the population health problems had been carried out, almost in a traditional way, from the statistical information on morbidity and mortality registered by health institutions. However, with increasing clarity, reality shows that the measures obtained from such categories are now insufficient to describe the increasingly complex health problems in which our society is immersed ${ }^{2}$.

In this vein, relatively new concepts are framed (at least in their quantification) for knowledge of the quality of care and medical complaint, the latter as a contrary indicator of the first, for whose analysis and evaluation require new statistics that document these aspects. For example, this is the case with the figures on the adverse incidents that have been integrated from the International Classification of Patient Safety, favoring a new category of information.

It should be noted that little is known about the reasons that lead the population to present or not a complaint. However, there is an absolute consensus in mentioning that its presentation occurs, to a large extent, due to factors such as the opinion of another doctor when disqualifying colleagues in terms of their performance, the presence of a more demanding and better-informed society, the role played by specific media, and the increasingly growing industry of litigation against physicians ${ }^{3}$.

It is noteworthy that the complaints addressed in the context of medical arbitration are particularly valuable because they allow us to know three dimensions of the problem under multiple approaches: (a) that of the user of the services, based on the factual account delivered at the time of filing the complaint; (b) that of the health service provider, based on the documentation proving the care provided; and (c) that of the institutional expert of CONAMED, based on the specialized and impartial documentary review from a medical technical point of view. 
The objective of this report is to present the results found in the analysis of the 40 completed arbitrary award files that have been issued by CONAMED during the 2011-2015 period, corresponding to the user population under fifteen years of age, with particular emphasis on adverse incidents.

The implicit premise of this purpose is that not knowing our reality leads to not being aware of the risks that exist regarding the occurrence of adverse incidents and, therefore, to the non-implementation of measures to improve the quality of the health services provided, which implies not working in the prevention of damage to patients.

\section{Methods}

Although CONAMED has an institutional system of data recording, this is an administrative one, whose function is to follow up on the cases attended in the various phases of the process, so that the obtained databases do not necessarily have the desired level of disaggregation of the different variables and categories of analysis. That is why, since the end of 2014, ARIEL project was executed, which, as already mentioned, consists in reviewing and analyzing the complaints concluded by issuing arbitrary awards.

The process begins with the review of the files formed on the occasion of the formal filing of the complaint. Based on an expressly designed format, the information that can be quantified is codified from defined catalogs ${ }^{4}$ (among which three are international, several national, sectoral and institutional $)^{b}$, in such a way that a robust statistic is generated on the arbitrary awards concluded. To date, we have data for the past 5 years, 2011-2015, adding approximately 350 reports analyzed, of which 40 cases refer to users under 15 years of age. It should be mentioned that the arbitrary awards include complaints from both private and public sectors (with the exception of the Mexican Social Security Institute, as it is an institution that does not submit to the arbitration process carried out by CONAMED under the argument that it has the legal resources for the resolution of conflicts within the institution itself $)^{5}$.

For this analysis, a descriptive and transversal study was carried out which includes the main variables

b It includes the International Classifications of Diseases (ICD-10), procedures (CIE_9MC), patient safety (CISP); National Catalogs of Territorial Integration of INEGI (localities, municipalities and federative entities), Catalog of Occupations, Disability, Medical Specialties (SEP/DGP), Health facilities (SSA/CLUES), among the most relevant.
Table 1. Distribution by age and sex of the users of health services under 15 years old corresponding to the arbitrary awards of the 2011-2015 period

\begin{tabular}{|l|c|c|c|}
\hline \multirow{2}{*}{ Age groups (years) } & \multicolumn{2}{|c|}{ Sex } & \multirow{2}{*}{ Total (\%) } \\
\cline { 2 - 3 } & Male & Female & \\
\hline$<1$ & 8 & 5 & $13(32.5)$ \\
\hline $1-4$ & 3 & 4 & $7(17.5)$ \\
\hline $5-9$ & 5 & 3 & $8(20)$ \\
\hline $10-14$ & 4 & 8 & $12(30)$ \\
\hline Total & 20 & 20 & $40(100)$ \\
\hline
\end{tabular}

captured in the conceptual framework of the project mentioned above. The statistical management was carried out from Excel $^{\circledR}$ databases, from which simple frequencies, percentage distributions, proportions, and ratios were obtained. The confidentiality of personal data was ensured at all times, as indicated in the corresponding legislation.

\section{Results}

The structure of the article responds to the Mexican Model of Medical Arbitration ${ }^{6}$, which addresses the different facets to be considered in the analysis of the complaint: the sociodemographic characteristics of the user, the features of the medical establishments involved and health care, the damages of the user population and the reasons for the complaint, the events of adverse effects and patient safety, as well as the institutional performance with respect to the evaluation of the medical act and the conclusion of the arbitrary award.

\section{Sociodemographic characteristics of the user population}

In general terms, the majority of users treated in the medical arbitration processes of the institution are female. In the present case, of the 40 arbitrary awards that were issued during the analyzed period, an equitable behavior was observed regarding sex: 20 males and 20 females. The distribution by age also shows a homogeneous distribution, with the highest percentages in the extreme ages of this population segment: under 1 year (32.5\%) and 10-14 years (30\%) and very similar in the other two age groups (Table 1).

As for the place of residence, the population claimed to reside in some of the 12 states of the country. As 
Table 2. Institution involved in the medical complaint according to the type of establishment, period 2011-2015

\begin{tabular}{|l|c|c|c|c|}
\hline \multirow{2}{*}{ Institution* } & \multicolumn{3}{|c|}{ Types of establishment } & \multirow{2}{*}{ Total (\%) } \\
\cline { 2 - 5 } & External consultation & Hospitalization & Support & $7(17.5)$ \\
\hline SSA & 1 & 6 & & $7(17.5)$ \\
\hline ISSSTE & 1 & 6 & - & $2(5)$ \\
\hline State & - & 2 & 1 & $24(60)$ \\
\hline Private & 10 & 13 & 1 & $40(100)$ \\
\hline Total & 12 & 27 & & 400 \\
\hline
\end{tabular}

*The Mexican Institute of Social Security, which presents the largest volume of total complaints, does not submit to the arbitration process of CONAMED. SSA: for the Spanish acronym of Ministry of Health; ISSSTE: for the Spanish acronym of Institute of Security and Social Services of State Workers

expected, the majority declared living in Mexico City (18 cases, $45 \%$ of users), following in importance the State of Mexico (four cases), Guanajuato and Yucatán (three cases in each), and Aguascalientes, Chihuahua, Michoacán, and San Luis Potosí (two cases from each state).

Unfortunately, no information was available to locate the level of vulnerability of the dissatisfied population with medical attention, since, for the information system and the outline of the record of awards, it is not obligatory to provide information on level of education, occupation, or ascription to social security (in this case of the parents of the affected children).

\section{Medical care and condition that caused the complaint}

It is vital to know the sector and the institution where the incident that originated the filing of the claim occurred. The available data show that, in $60 \%$ of the cases $(n=24)$, the children were treated in the private sector, while in the other, $40 \%(n=16)$ were treated in public health institutions: seven cases in the Institute of Security and Social Services of State Workers (ISSSTE, for its Spanish acronym), seven in the Ministry of Health, and two in State Services (Table 2).

It should be noted that the type of establishment where the first care was provided was mostly a hospital unit: 27 of the 40 cases $(67.5 \%)$ initially went to a hospital seeking care, while 12 cases $(30 \%)$ initiated care of the health problem in a first-level outpatient unit. A support facility (laboratory) was responsible for the additional case.

\section{Principal services involved}

As expected, most of the complaints of the user population engaged in the controversies that are now described came from the pediatric services $(42.5 \%, 17 \mathrm{ca}-$ ses), followed by the emergency and gynecology-obstetric services, with five complaints (12.5\%); the third site corresponded to dentistry, with four complaints (10\%). Furthermore, three cases appear from both general surgery and traumatology and orthopedics (7.5\% each). It is worth noting that the vast majority of cases from pediatrics were attended by private facilities, as well as all cases of dentistry. As for the cases from emergency services, most of them were treated in units of the public sector.

\section{Reasons for the complaint}

As for the reasons that gave rise to the controversy, these can be analyzed under two different levels of disaggregation: that is, considering only the leading cause (globally and in large groups) or taking into account the total of causes with a higher level of disaggregation.

Considering only the main reason (40 reasons stated) mentioned in the general approach to the complaint, $45 \%$ of the claimants ( 18 cases) cited problems related to the diagnostic methods; in particular, 13 specifically reported delays in carrying out certain procedures. With equal relative weight $(20 \%)$, there were reasons related to the delivery and puerperium care ( 8 cases), as well as reasons related to the diagnosis (5 of 8 causes). Three other cases recorded post-operative complications within the treatment group, to mention the most important ones. 
Table 3. Reasons mentioned at the time of filing the complaint, according to large disaggregated groups, period 2011-2015

\begin{tabular}{|c|c|c|}
\hline Code & Reasons for the complaint according to arbitrary final awards & Total (\%) \\
\hline & Delivery and puerperium care & $28(13.4)$ \\
\hline 1.1 & Accidents and incidents & $2(1)$ \\
\hline 1.3 & Delivery care by unqualified personnel & $2(1)$ \\
\hline 1.4 & Complications of pregnancy on the mother & $3(1.4)$ \\
\hline 1.5 & Complications of pregnancy on the product & $1(0.5)$ \\
\hline 1.6 & Complications of delivery on the mother & $1(0.5)$ \\
\hline 1.7 & Complications of delivery on the product & $1(0.5)$ \\
\hline 1.8 & Complications of the puerperium & $2(1)$ \\
\hline 1.9 & Lack of prenatal control or inadequate control & $2(1)$ \\
\hline 1.13 & Lack of follow-up or inadequate monitoring of the puerperium & $3(1.4)$ \\
\hline 1.15 & Delayed or denial of the delivery care & $2(1)$ \\
\hline 1.16 & Inadequate follow-up of labor & $5(2.4)$ \\
\hline 1.17 & Inadequate technique & $2(1)$ \\
\hline \multirow[t]{2}{*}{1.18} & Inadequate evaluation of hospital discharge & $2(1)$ \\
\hline & Diagnostic methods & $27(12.9)$ \\
\hline 2.2 & Unnecessary studies & $3(1.4)$ \\
\hline 2.3 & False positives or negatives & $4(1.9)$ \\
\hline 2.5 & Delayed diagnostic procedure & $17(8.1)$ \\
\hline 2.6 & Delay or lack of notification of results & $1(0.5)$ \\
\hline \multirow[t]{2}{*}{2.7} & After-effects & $2(1)$ \\
\hline & Diagnosis & $47(22.5)$ \\
\hline 3.1 & Disinformation about diagnosis & $7(3.3)$ \\
\hline 3.2 & Misdiagnosis & $16(7.7)$ \\
\hline 3.3 & Diagnostic omission & $6(2.9)$ \\
\hline \multirow[t]{2}{*}{3.4} & Delay in diagnosis & $18(8.6)$ \\
\hline & Medical treatment & $47(22.5)$ \\
\hline 4.1 & Accidents and incidents & $2(1)$ \\
\hline 4.2 & Secondary complications & $8(3.8)$ \\
\hline 4.3 & Disinformation about the treatment & $1(0.5)$ \\
\hline 4.4 & Lack of consent & $1(0.5)$ \\
\hline 4.5 & Delayed treatment & $12(5.7)$ \\
\hline 4.6 & After-effects: therapeutic excess & $3(1.4)$ \\
\hline 4.7 & Inappropriate or unnecessary treatment & $13(6.2)$ \\
\hline 4.8 & Unsatisfactory treatment & $6(2.9)$ \\
\hline 4.9 & Others & $1(0.5)$ \\
\hline
\end{tabular}


Table 3. (Continued)

\begin{tabular}{|c|c|c|}
\hline Code & Reasons for the complaint according to arbitrary final awards & Total (\%) \\
\hline & Surgical treatment & $30(14.4)$ \\
\hline 5.1 & Accidents and incidents & $4(1.9)$ \\
\hline 5.2 & Premature discharge of post-operative care & $2(1)$ \\
\hline 5.3 & Unnecessary surgery & $4(1.9)$ \\
\hline 5.4 & Surgical complications after surgery & $1(0.5)$ \\
\hline 5.6 & Surgical error & $1(0.5)$ \\
\hline 5.8 & Lack of follow-up or inadequate follow-up in the post-operative period & $2(1)$ \\
\hline 5.9 & Lack of pre-surgical assessment & $6(2.9)$ \\
\hline 5. 10 & Delay of surgical treatment & $5(2.4)$ \\
\hline 5.11 & After-effects & $2(1)$ \\
\hline \multirow[t]{2}{*}{5.12} & Inadequate surgical technique & $3(1.4)$ \\
\hline & Doctor-patient relationship & $20(9.6)$ \\
\hline 6.1 & Disinformation about diagnosis & $7(3.3)$ \\
\hline 6.2 & Communication failures & $12(5.7)$ \\
\hline \multirow[t]{2}{*}{6.3} & Inappropriate treatment & $1(0.5)$ \\
\hline & Administrative deficiencies & $10(4.8)$ \\
\hline 7.1 & Change of physician or medical unit & $1(0.5)$ \\
\hline 7.2 & Delay or deferral to obtain the service & $1(0.5)$ \\
\hline 7.3 & Lack of medical equipment & $3(1.4)$ \\
\hline 7.4 & Lack of supplies or medications & $1(0.5)$ \\
\hline 7.7 & Reference and counter-reference system & $2(1)$ \\
\hline 7.8 & Inadequate treatment by administrative staff & $1(0.5)$ \\
\hline \multirow[t]{2}{*}{7.9} & Others & $1(0.5)$ \\
\hline & Total & $209(100)$ \\
\hline
\end{tabular}

The total number of reasons mentioned in the complaint is 209; that is, an average of 5.2 causes per analyzed case (Table 3 ).

\section{Morbidity origin of the incident that gave rise to the complaint}

The morbidity presented by the user population of the health systems, whose medical attention gave rise to the presentation of a complaint, is shown at the level of the major chapters of the International Classification of Diseases. As observed, the highest frequency of cases corresponds to diseases of the digestive system $(n=8)$, followed by certain conditions originating in the perinatal period ( $n=5)$, as well as diseases of the respiratory system $(n=4)$ and congenital malformations $(n=4)$ (Table 4).

\section{Patient safety}

When analyzing the quality of medical care, one of the key components must be patient safety. The incidents that occur in the hospital environment impact to varying degrees both the population and the physician involved. Even the very credibility of the health system as a whole, not only from the health point of view, but 
Table 4. Causes of morbidity in the 40 awards analyzed

\begin{tabular}{|l|l|c|}
\hline Group & Causes of morbidity by group & Cases n (\%) \\
\hline I & Certain infectious and parasitic diseases & $2(5)$ \\
\hline II & Neoplasms & $2(5)$ \\
\hline IV & Endocrine, nutritional, and metabolic diseases & $1(2.5)$ \\
\hline IX & Circulatory system diseases & $1(2.5)$ \\
\hline VII & Diseases of the nervous system & $2(5)$ \\
\hline X & Diseases of the eye and its annexes & $1(2.5)$ \\
\hline XI & Diseases of the respiratory system & $4(10)$ \\
\hline XIII & Diseases of the digestive system & $8(20)$ \\
\hline XIV & Diseases of the musculoskeletal system and connective tissue & $2(5)$ \\
\hline XIX & Diseases of the genitourinary system & $2(5)$ \\
\hline XVI & Injuries, poisonings, and some other consequences of external cause \\
\hline XVII & Certain conditions originating in the perinatal period & $3(7.5)$ \\
\hline XVIII & Congenital malformations, deformities, and chromosomal abnormalities & $5(12.5)$ \\
\hline XXI & Symptoms, signs and abnormal findings, not classified elsewhere & $4(10)$ \\
\hline & Factors that influence the state of health and contact with health services & $2(5)$ \\
\hline
\end{tabular}

also from the economic, social and, even, legal point of view ${ }^{7}$. When talking about adverse incidents ${ }^{c}$, they are considered as those events where there was, or could have been, unintended damage to the patient ${ }^{8}$.

It is worth mentioning a critical limitation in the analysis that is now presented since there are no denominators that frame this problem in the national context or a more global scope of the health system. That is why, this section is limited to describe the categories of adverse

c According to the International Classification of Patient Safety, an adverse event is an event that meets one or more of the criteria listed below: (1) a patient has been injured, regardless of the possible responsibility of the hospital; (2) the admission was the result of an adverse effect of ambulatory care; (3) the patient has been admitted again due to complications or incomplete care in the previous admission; (4) there have been deficiencies in the documentation, for example, in the informed consent procedures or the clinical history; (5) an unforeseen surgical intervention has been carried out; (6) procedures that did not meet hospital suitability criteria have been used; (7) a problem has arisen with the use of blood or blood products; (8) there has been a nosocomial infection (contracted in the hospital); (9) drugs have been used incorrectly; (10) there has been a cardiac or respiratory arrest or death; (11) an incident has occurred (such as a patient's fall); (12) abnormal radiological or laboratory data have not been monitored; (13) the stay has been abnormally short or long for the disorder; (14) there have been problems to obtain services; (15) the patient or family have been dissatisfied. incidents found in the files of completed arbitrary awards and their percentage distribution and to show an indicator on the relative incidence of each item ${ }^{d}$ (Table 5).

In the case of the present analysis, concerning the 40 complaints resolved through medical arbitration within the 2011-2015 period, a total of 351 incidents or adverse events were found, which averages approximately 8.8 for each case. These incidents have been organized based on an abbreviated list of adverse events (seven large groups), which is disaggregated into a little more than 84 categories (Table 3).

According to the organization, as mentioned earlier, the following results stand out:

- The highest frequency of adverse events corresponded to the problems related to the procedures (91 incidents), which represents $25.9 \%$ of the total and a relative incidence of 127 events per hundred cases. In particular, the categories of ineffective or inefficient medical treatment, lack of treatment facilities, and incomplete or ineffective surgical intervention were highlighted within this group.

\footnotetext{
d As a general context, it is worth mentioning that a study conducted in two hospitals of the public sector during 2006 indicated a prevalence of $11.8 \%$ of adverse events with respect to total out-of-hospital expenses.
} 
Table 5. Adverse incidents by significant categories in the 40 arbitrary awards analyzed for the period 2011-2015

\begin{tabular}{|l|l|c|c|c|}
\hline Code & Adverse events & Total & Percentage distribution & Incidence* \\
\hline $\mathrm{Ge}$ & Adverse incidents related to management & 51 & 14.5 & 127.5 \\
\hline $\mathrm{Co}$ & Adverse incidents related to communication & 46 & 13.1 & 115 \\
\hline $\mathrm{Di}$ & Adverse events related to diagnosis & 50 & 14.2 & 125 \\
\hline $\mathrm{Pr}$ & Adverse events related to procedures & 91 & 25.9 & 227.5 \\
\hline $\mathrm{Me}$ & Adverse events related to medications & 65 & 18.5 & 162.5 \\
\hline $\mathrm{Cu}$ & Adverse events related to care & 37 & 10.5 & 92.5 \\
\hline $\mathrm{In}$ & Adverse events related to infections & 11 & 3.1 & 27.5 \\
\hline
\end{tabular}

*The denominator of the incidence corresponds to the 40 cases analyzed

- The incidents related to medication problems $(n=$ 65) followed, concentrating $18.5 \%$ of the total incidents, which implies 162 incidents per hundred presented complaints. The most frequently reported categories were the inadequate preparation of the medication, the errors in the handling of the medicine, the delay in its administration, and the incorrect monitoring of the drug. It is striking that, in the international literature, this group of incidents always appears as the most frequent in pediatric patients, which does not happen with the present data; the reason may be that the user (or their relatives in this case) does not always realize what happened, and in the factual account, they are not necessarily mentioned. Similarly, in the documentation included by the providers, the emphasis is placed on the procedures performed and not so much on the details of the process as could be the medication, usually by the nursing staff, who do not in all cases present their control sheets.

- Immediately after, the incidents originated by the administrative management $(n=51)$ appeared, representing $14.5 \%$ of the global events, which would imply, regarding relative incidence that 127 per hundred similar cases would occur. The main categories mentioned in this group refer to problems with an incomplete file, including the loss of documentation, followed by a long waiting list.

- With frequency close to the previous group, adverse incidents related to the diagnosis were found $(n=50)$, which means $14.2 \%$ of the total number of events and which implies, in relative terms, a potential occurrence of 125 incidents per every hundred disagreements or complaints. The categories that stood out relevantly were not having exhausted the means for the diagnosis, misdiagnosis, and delay in its detection.

- In the fifth place, there were communication problems $(n=46)$ between medical personnel and family members or with nursing staff, even between two or more doctors. This group concentrated $13.1 \%$ of the total events, and its relative incidence was 115 adverse events for every hundred complaints presented.

- Adverse incidents related to childcare $(n=37)$ were found in the penultimate place, representing a little more than $10 \%$ of the total incidents registered globally; its relative incidence implied waiting for the occurrence of 93 events for every hundred complaints. In the case of the pediatric population, only one category stood out: the inadequate follow-up of the patient's evolution.

- The group of infections associated with health appeared with the lowest number of cases $(n=11)$, even when, together with the frequency, it implied the highest lethality, particularly in the youngest ages of this population stratum. It represented $3.1 \%$ of the cases, with a relative incidence of 28 infectious events for every 100 complaints analyzed. They highlighted the categories of surgical wound infection, sepsis, and septic shock, as well as nosocomial pneumonia.

\section{Damage suffered as a result of the alleged medical care}

\section{DeATHS}

In accordance with the documents included in the medical-legal files drawn on the occasion of the 40 complaints, presumably as a result of the 
Table 6. Type of disability suffered by health services users in the 40 analyzed arbitrary awards of the period 2011-2015

\begin{tabular}{|l|c|}
\hline Type of disability & Total (\%) \\
\hline Motor disability & $7(50)$ \\
\hline Sensory and communication impairment & $4(28.6)$ \\
\hline Multiple disabilities & $1(7.1)$ \\
\hline Unspecified disabilities & $2(14.3)$ \\
\hline Total & $14(100)$ \\
\hline
\end{tabular}

concatenation of one or more of the mentioned adverse events, there were 12 deaths of children under 15 years of age (seven males and five females, half of them under one year of age) during the analysis period. Due to their seriousness, these deaths are considered as alleged sentinel events. ${ }^{e}$ The relationship between the number of deaths concerning the total number of cases shows a very high index, which implies a relative incidence of 30 deaths per hundred cases analyzed $(12 / 40)$, which relativizes the seriousness of the problem.

Among the causes of deaths are some linked to diseases of the circulatory system (four cases), the respiratory system (one case), related to the nervous system (one case), with endocrine, nutritional and metabolic diseases (one case), with certain conditions in the perinatal period, with malignant neoplasms (one case) and some others of an unspecified nature (three cases).

\section{Presence and type of Disability}

Regarding the consequences suffered by the alleged poor care received, in addition to the 12 deaths mentioned above, in 14 cases, disability cases were reported, as shown in table 6 . In the other 14 cases, those affected did not mention these kinds of problems.

As can be seen, in half of the cases, motor disabilities were reported $(n=7)$, followed by sensory and communication impairments $(n=4)$. One case mentioned a multiple disability, and in two cases, although the problem was mentioned, the disability was not specified (Table 6). From these figures, an incidence can be estimated concerning the severity of the damage suffered by some limitation, a value that amounts to

e It is viewed as a sentinel event, an unexpected event resulting from medical care, which produces death, the loss of a function or an organ.
35 cases for every hundred complaints analyzed $(14 / 40)$. This figure is slightly modified if we take into account that there are nine qualified cases with a permanent disability, with the incidence of permanent disability remaining at 22.5 cases for every hundred complaints received.

A very general indicator on the presence of damage would be given by the consideration of the existence of death or permanent disability in cases of completed arbitrary awards (21/40), which indicates that 52 of every 100 users under 15 years of age submitted to the arbitration process in CONAMED suffered permanent disability or death.

\section{Evaluation of the medical action and conclusion of the arbitrary award}

One of the substantive phases of the process of review and analysis of the evidentiary documentation delivered to CONAMED by the parties involved in the medical-legal conflict is the evaluation process of the medical action, to find the objective elements about the evidence or not of malpractice. The importance of this phase is the moment of the process in which it is determined, whether the damages or clinical events reported or documented by the parties involved are inherent aspects of the natural history of the disease or if they are due to treatment omissions by the patient or if they are consequences of the medical action itself.

In this sense, of the review of the 40 arbitrary awards of children under 15 years of age from the pediatric services concluded during the 2011-2015 period, it was determined that $26(65 \%)$ did have elements of medical malpractice, in so much that 14 did not show such evidence $(35 \%)$ (Table 7).

The institutional behavior is interesting, because although half of the arbitrary awards with evidence of malpractice correspond to the private sector, the proportion concerning the total within that same sector was the lowest of all, with $54 \%$ (that is, $13 \%$ of 24 ), while this indicator increased to $71.4 \%$ for the ISSSTE and $88.9 \%$ for the Ministry of Health and state services considered jointly.

Although the documentary evaluation of the medical act is of utmost importance for the opinion of the final judgment by the institutional experts, the conclusion of the arbitrary award does not occur automatically from the previous determination, since those results are considered the light of the claimants' specific demand, and it may happen that the malpractice is disconnected 
Table 7. Resolution of the arbitrary award in the 40 cases analyzed

\begin{tabular}{|l|c|c|c|c|c|}
\hline \multirow{2}{*}{ Institution involved } & \multicolumn{2}{|c|}{ Medical act assessment } & \multirow{2}{*}{ Total arbitrary awards } & \multicolumn{2}{|c|}{ Conclusion of the arbitrary award } \\
\cline { 2 - 5 } & $\begin{array}{c}\text { With evidence of } \\
\text { malpractice }\end{array}$ & $\begin{array}{c}\text { No evidence of } \\
\text { malpractice }\end{array}$ & Conviction & Acquittal \\
\hline SSA & 6 & 1 & 7 & 6 & 1 \\
\hline State services & 5 & 2 & 7 & 2 & 2 \\
\hline ISSSTE & 2 & 0 & 24 & 1 & 13 \\
\hline Private & 13 & 11 & 40 & 24 & 16 \\
\hline Total & 26 & 14 & & 2 & 2 \\
\hline
\end{tabular}

SSA: Ministry of Health for its Spanish acronym; ISSSTE: Institute of Security and Social Services of State Workers for its Spanish acronym

from the main reason for the complaint. This is called non-binding malpractice.

According to the final judgment issued concerning the 40 awards, $60 \%(n=24)$ received the verdict of conviction, while the other 16 (remaining 40\%) were acquittals. The immediate consequence of this is that, while in the first case, the plaintiffs have the right to receive payment of the compensation or reimbursement requested, and in the case of acquittals, the service provider is exempt from having to cover the claims demanded by the user.

It should be noted that, in some cases, the process does not end with the ruling of the judgment, as it happens that the plaintiff (or the defendant) is entitled to disagree with the institutional determination made and in that case proceed to the presentation of an amparo. This was the case of seven of the 40 awards concluded, of which three were covered concerning the Ministry of Health, three against the ISSSTE and one against the state's health services.

\section{Discussion}

Although there are no objective elements to affirm that the safety of the pediatric patient has improved in recent years, since there is no information documenting such behavior, it could be inferred that knowledge is increasingly taken into account of the adverse incidents that actually or potentially affect the user population of health services in Mexico ${ }^{9-12}$. Thus, there is a need to promote the dissemination and knowledge of this topic and the concepts that are specific to them, both in the Pediatrics area and any other service or specialty. The medical and health personnel must know the risks and the consequences where these incidents derive so that particular attention is paid, in all contexts, to the doctor-patient relationship. This relationship will not only improve the quality of the service provided but also avoid disagreements and complaints, as well as the physical and emotional damage that this entails, not only for the user population and their immediate environment but also for doctors and staff of health as second victims of these conflicts.

\section{Ethical disclosures}

Protection of human and animal subjects. The authors declare that no experiments were performed on humans or animals for this study.

Confidentiality of data. The authors declare that no patient data appear in this article.

Right to privacy and informed consent. The authors declare that no patient data appear in this article.

\section{Acknowledgments}

The authors would like to thank Dr. Rafael Rodríguez for his support in the handling of information.

\section{Funding}

None.

\section{Conflicts of interest}

The authors declare no conflicts of interest.

\section{References}

1. Comisión Nacional de Arbitraje Médico. México: Proyecto ARIEL. Marco conceptual y documentos técnicos que lo integran. 2017. Available at: http://www.conamed.gob.mx/publicaciones/ariel.php. 
Bol Med Hosp Infant Mex. 2018;75

2. Hernández F, Aguilar MT, Santacruz Varela J, Rodríguez Martínez Al, Fajardo Dolci GE. Queja médica y la calidad de la atención. Rev CONAMED. 2009;14:26-34.

3. Aguirre Gas H, Campos Castolo EM, Carrillo Jaimes A, Zavala Suárez E Fajardo Dolci GE. Análisis crítico de la queja médica. Rev CONAMED. 2008;13:5-16.

4. World Health Organization. The conceptual framework for the International Classification for Patient Safety Version 1.0 for use in field testing 2007-2008. WHO; 2017. Available at: http://www.who.int/patientsafety/ ICPS\%20-\%20July\%202007.pdf.

5. Ley del Seguro Social, Artículo 296 (reformado 20-12-2001). Diario Oficial de la Federación.

6. Secretaría de Salud. Modelo de Arbitraje Médico. México; 2017. Available at: http://www.salud.gob.mx/unidades/cdi/documentos/DOCSAL7339.pdf.

7. Estudio Nacional sobre los efectos adversos ligados a la hospitalización (ENEAS), 2005. Dirección General de la Agencia de Calidad del Sistema
Nacional de Salud. Reporte 2006. Madrid: Ministerio de Sanidad y Consumo; 2006

8. Lezana MA, Fernández S, Rodríguez J. Laudos 2007-2011: aprendiendo sobre los incidentes adversos y otras características de la queja médica. Rev CONAMED. 2015;20:101-10.

9. Observatorio del Desempeño Hospitalario 2006. Secretaría de Salud/ Dirección General de Evaluación del Desempeño. México; 2007. Available at: www.dged.salud.gob.mx

10. Infante C. Quejas médicas: la insatisfacción de los pacientes con respecto a la calidad de la atención médica. México: Editores de Textos Mexicanos; 2006.

11. Dubyn MC, Romero ME. Análisis de controversias en arbitraje médico. Rev CONAMED. 2012;17:100-8.

12. Bustamante-Leija LE, Maldonado-Camargo VM, González-Anaya C, Gutiérrez Vega R. Mecanismos alternativos de solución de controversias en la prestación de servicios de salud. Rev CONAMED. 2012;17:126-9. 